\title{
Hospitalitas Abimelekh dan Peringatan Allah: Analisis Naratif Kejadian 20:1-18 dan Relevansinya Terhadap Peringatan yang Disertai Kekerasan
}

\author{
Cindy Patandianan ${ }^{1}$, Frans Paillin Rumbi ${ }^{2}$, Sumiati ${ }^{3}$ \\ Institut Agama Kristen Negeri Toraja ${ }^{1}$, Institut Agama Kristen Negeri Toraja ${ }^{2}$, Institut Agama Kristen \\ Negeri Toraja ${ }^{3}$ \\ email korespondensi: cindypatandianan@gmail.com
}

\begin{abstract}
This paper aims to examine the story of Abimelech and God by using narrative interpretation as a model approach to answer the question of how is the hospitality shown by Abimelech? Does a good host deserve a warning for the fault of the guest's carelessness? Does the host need to resort to violence against a stranger who harms him? From this article, we will explore what is the background of God's stern warning to Abimelech through dreams. The approach used is the approach approach. The results of the study show that God Abimelech strictly when he was not married Sarah was already married, namely (1) the possibility of Abimelech from the danger of committing sins. (2) the punishment, preventing "all the women in Abimelech's house from becoming pregnant", lasted only so long as Abimelech was in danger of sleeping with Sarah. it was to change the situation, not for Abimelech. (3) the punishment clearly shows that Abraham was in fellowship with Almighty God. this incident probably made Abimelech respect and fear the God of Abraham. Thus, it can be said that the memory of virtue values when directing a person to turn away from deviant behavior.
\end{abstract}

Keywords: hospitality, Abimelech, Abraham, God, warning

\begin{abstract}
Abstrak: Tulisan ini hendak mengkaji kisah Abimelekh dan Tuhan dengan menggunakan tafsir naratif sebagai model pendekatan untuk menjawab pertanyaan bagaimana hospitalitas yang ditunjukkan oleh Abimelekh? Apakah seorang tuan rumah yang baik patut mendapat peringatan karena kesalahan yang ditimbulkan oleh kecorobohan sang tamu? Apakah sang tuan rumah perlu melakukan kekerasan terhadap orang asing yang mencelakakkannya?. Dari tulisan ini akan mendalami apa yang menjadi latar belakang dari peringatan keras Allah kepada Abimelekh melalui mimpi. Pendekatan yang digunakan adalah pendekatan kualitatif. Hasil dari penelitian menunjukkan bahwa Tuhan memperingatkan Abimelekh dengan keras ketika dia tidak tahu Sarah sudah menikah, yaitu (1) menjauhkan Abimelekh dari bahaya berbuat dosa. (2) hukuman, mencegah "semua wanita di rumah Abimelekh untuk hamil," hanya berlangsung selama Abimelekh dalam bahaya tidur dengan Sarah. itu dimaksudkan untuk mengubah situasi, bukan untuk menyakiti Abimelekh. (3) hukuman dengan jelas menunjukkan bahwa Abraham bersekutu dengan Tuhan Yang Mahakuasa. kejadian ini mungkin membuat Abimelekh menghormati dan takut akan Tuhan Abraham. Dengan demikian, dapat dikatakan bahwa ingatan menampakkan nilai kebajikan ketika ditujukan untuk mengarahkan seseorang berbalik dari perilaku menyimpang.
\end{abstract}

Kata kunci : hospitalitas, Abimelekh, Abraham, Allah, peringatan

Article History

\begin{tabular}{|l|l|l|}
\hline Submitted: 20 Oktober 2021 & Revised: 3 Februari 2022 & Accepted: 4 Februari 2022 \\
\hline
\end{tabular}

\section{PENDAHULUAN}

Apakah Tuhan melakukan kejahatan? Pertanyaan profokatif ini hampir pasti ditolak, orang beragama. Tuhan selalu ditempatkan sebagai yang sakral karena ia suci dan tidak bersalah. Tindakan-Nya selalu dipandang baik dan benar kepada semua orang, tidak peduli, seseorang hidup bahagia atau menderita. Berbagai kisah Alkitab 
memperlihatkan cara Tuhan menegur dan menghukum umatNya, namun kisah selalu berakhir dengan penyelamatan. Teguran dan hukuman merupakan dua metode yang seringkali digunakan Tuhan untuk mengingatkan umat atas salah dan dosanya.

Ingatan menampakkan nilai kebajikan ketika ditujukan untuk mengarahkan seseorang berbalik dari perilaku menyimpang. Ingatan yang disampaikan sebagai teguran, disebut peringatan. Sementara, ingatan yang sifatnya mengenang sebuah peristiwa (kata dan tindakan) disebut dengan mengingat. Ingatan merujuk pada standar moral baik berupa perjanjian, aturan atau norma-norma yang telah disepakati bersama. Meskipun penggunaan, ingatan selalu mengandung pengetahuan tentang yang baik, kepedulian serta tindakan mengajak orang lain merefleksikan kembali perjalanan hidupnya.

Peringatan dan mengingatkan akan bemakna apabila perjumpaan dilandasi oleh spirit hospitalitas (keramahtamahan). Hal ini akan membuat pihak-pihak yang menjalin relasi tidak terluka oleh kata dan tindakan orang lain. Joas Adiprasetya menjelaskan bahwa istilah hosptialitas berasal dari kata hospes (Latin) yang berarti tamu dan tuan rumah. Kata hospitalitas bersifat ambigu karena seorang tamu dapat bertindak sebagai orang asing tetapi juga dapat bertindak sebagai musuh. Akan tetapi dalam Alkitab, kata hospitalitas mendapat konotasi positif yakni mengasihi dan bersahabat dengan orang asing.

Kejadian 20: 1-18 mempertemukan hosptialitas Abimelekh dan peringatan Tuhan dalam sebuah kisah yang kontroversial. Abimelekh berusaha menunjukkan dirinya sebagai tuan rumah yang baik saat menerima orang asing yakni Abraham dan Sarah. Akan tetapi tindakan berbeda dilakukan sang tamu, yakni mencari kenyamanan sendiri, tidak peduli perbuatannya dapat mencelakakan tuan rumah. Kontroversi semakin memanas ketika, sang tuan rumah yang baik justru mendapat peringatan dari Tuhan. Peringatan itu tidak berlandaskan sebuah kesepakatan moral atau perjanjian tertentu. Namun Tuhan bermaksud menerapkannya pada orang lain.

Peneliti hendak mengkaji kisah Abimelekh dan Tuhan dengan menggunakan tafsir naratif sebagai model pendekatan untuk menjawab pertanyaan bagaimana hospitalitas yang ditunjukkan oleh Abimelekh? Apakah seorang tuan rumah yang baik patut mendapat peringatan karena kesalahan yang ditimbulkan oleh kecorobohan sang tamu? Apakah sang tuan rumah perlu melakukan kekerasan terhadap orang asing yang mencelakakkannya?

Analisis terhadap kisah tersebut, hendak digunakan untuk menjawab persoalan-persoalan yang dihadapi terkait cara memperlakukan seorang tamu, 
apalagi jika sang tamu telah melakukan hal-hal yang tidak menyenangkan bagi tuan rumah. Hospitalitas dan peringatan sama-sama dibutuhkan agar tuan rumah dan tamu hidup dalam perdamaian dan terhindar dari konflik.

\section{METODE}

Metode yang digunakan adalah metode analisis naratif. Analisis naratif yaitu metode untuk memahami dan mengkomunikasikan pesan alkitabiah yang sesuai dengan bentuk kisah dan kesaksian personal, sesuatu yang merupakan ciri khas dari Kitab Suci dan suatu model fundamental dari komunikasi antarmanusia (Alexander \& Tarmedi, 2013) Dalam tafsir naratif ini memusatkan perhatian hanya pada teks dan tidak merasa terlalu perlu bertanggungjawab atas semua aspek lain yang melatarbelakangi teks tersebut (Alexander \& Tarmedi, 2013). yang menjadi perhatian utama bukan lagi maksud pengarang aslinya, melainkan struktur literernya dan dinamika kisah yang memunculkan arti tersendiri. Pembaca dibawa untuk melihat ke tataran yang lebih tinggi dari maksud pengarang dan pertanyaan-pertanyaan historis, menuju arti yang dikandung oleh teks yang telah terpisah dari pengarangnya.

\section{HASIL DAN PEMBAHASAN}

Peringatan Allah kepada Abimelekh merupakan tanda kasih Allah kepadanya. Allah tidak menginginkan Abimelekh jatuh ke dalam dosa oleh karena itu la mencegahnya untuk berbuat jahat. Allah terlebih dahulu datang memberitahukan tentang hukuman yang akan dia tanggung apabila jatuh ke dalam dosa. NIV menuliskan alasan mengapa Tuhan menghukum Abimelekh ketika dia tidak tahu Sarah sudah menikah, yaitu (1) meskipun niat Abimelekh baik, selama Sarah tinggal di haremnya, dia dalam bahaya berbuat dosa. Seseorang yang memakan jamur payung beracun, mengira itu jamur yang tidak berbahaya, tidak diragukan lagi memiliki niat yang sangat baik, tetapi akan tetap menderita. dosa adalah racun yang merusak kita dan orang-orang di sekitar kita, apapun niat kita. (2) hukuman, mencegah "semua wanita di rumah Abimelekh untuk hamil," hanya berlangsung selama Abimelekh dalam bahaya tidur dengan Sarah. itu dimaksudkan untuk mengubah situasi, bukan untuk menyakiti Abimelekh. (3) hukuman dengan jelas menunjukkan bahwa Abraham bersekutu dengan Tuhan Yang Mahakuasa. kejadian ini mungkin membuat Abimelekh menghormati dan takut akan Tuhan Abraham.

Kekristenan memberi pengakuan bahwa sejarah ke-iman-an pada Allah dimulai dari Abraham (Kejadian 12-25). Baik Perjanjian Lama dan Baru memberi tempat 
tentang keteladanan iman yang diberikan Abraham. Dimulai dengan pemanggilannya dari Ur-Kasdim tempat ia tinggal bersama keluarganya menuju tanah kanaan hingga akhir hidupnya. Banyak kisah yang dilalui oleh Abraham dalam menjalani panggilan hidup Allah dalam kehidupannya. la adalah orang yang setia mengikuti perintah Allah. Namun tidak dapat dipungkiri bahwa sebagai manusia ia tak luput dari dosa. Ada saat dimana ia seakan mengabaikan untuk melakukan kehendak Allah demi mendapatkan rasa aman di tempat ia berada. Salah satu kisah dimana ketidaktaatan Abraham nampak yaitu ketika ia menipu Abimelekh raja Gerar bahwa Sara bukan istrinya tetapi saudaranya (Kejadian 20:1-18). Atas tindakan Abraham itu, hampir saja Allah mendatangkan celaka atas Abimelekh yang telah mengambil Sara. Hanya saja Abimelekh telah mendapat peringatan dari Allah melalui mimpi sehingga ia tidak berbuat dosa dengan cara menghampiri Sara istri Abraham.

\section{Latar Peristiwa}

Abraham berangkat dari Sodom dan Gomora yang telah dimusnahkan Allah dengan menurunkan hujan belerang dan api. Ketika Abraham memandang ke arah Sodom dan Gomora serta ke seluruh tanah lembah Yordan, maka dilihatnyalah asap dari bumi membubung ke atas sebagai asap dari dapur peleburan. la kemudian pergi ke tanah Negeb. Tanah Negeb merupakan suatu segi-tiga yang dibatasi oleh suatu garis yang mulai dari Gaza di tepi lautan tengah sampai ke sungai Mesir (Lempp, 2003). Senada dengan yang dikatakan oleh Kidner bahwa sebutan untuk Selatan adalah Negeb (RSV); lihat di 12:9. Paruh pertama dari ayat tersebut menceritakan tentang area umum pergerakan Abraham; kalimat terakhir mengarah ke cerita berikutnya yang terletak di suatu tempat sedikit ke utara, menuju Gaza (Kidner, 1967)

Negeb berarti tanah kekeringan atau tanah kekeringan air (Lempp, 2003). Tanah itu tak pernah merupakan gurun pasir, melainkan tanah perumputan yang dapat memberi jaminan kepada gembala dan kawanan kambing domba selama musim hujan. Tetapi dalam musim kemarau para gembala terpaksa berpindah ke daerah yang subur akan tanaman-tanaman demi kelangsungan hidup gembalaannya. Abraham kemudian berpindah lagi ke daerah Gerar sebab kurangnya hujan membuat rumput-rumput menjadi mati sehingga ternak Abraham tidak dapat memperoleh makanan untuk bertahan hidup. Perpindahan Abraham dari tanah Negeb selaku orang asing ke daerah Gerar yang merupakan daerah subur akan tanaman sesuai dengan apa yang disebut pemindahan tempat penggembalaan. Abraham menuju ke daerah Gerar karena terletak pada satu sungai (Kej. 26:17,19) yang tanahnya subur dan dapat 
ditanami. Musa juga dengan tegas menyatakan, bahwa ia tinggal sebagai orang asing di tanah Gerar (Calvin, 1578). Gerar mungkin terletak lima atau enam mil di sebelah selatan Gaza sehingga merupakan bagian dari wilayah yang diduduki bangsa Filistin. Sekalipun demikian, beberapa penafsir menduga bahwa Gerar terletak sekitar tiga belas mil di sebelah barat daya Kadesy (Maspaitella, 2014). Sebagai pengembara di Gerar, Abraham merasa takut jikalau ia akan dibunuh karena orang-orang akan mengambil Sara. la tidak akan merasa aman berada di Gerar apabila ia berstatus sebagai suami Sara. Penduduk asli Palestina (orang Gerar) tidak mengenal sopan santun sama sekali, juga tidak mengenal pengendalian diri dalam lapangan perkelaminan. Orang-orang pendatang itu berada dalam keadaan bahaya maut, sebab penduduk asli merasa tidak malu atau tidak ragu-ragu membunuh pengembara itu dan merampas wanitanya. Sebab itu orang-orang pengembara terpaksa memakai akal budi, tipu daya, kelicikan dan pintar-busuknya (Lempp, 2003). Abraham seorang pendatang di daerah itu berhati-hati dan mengambil tindakan pencegahan dengan mengakui bahwa ia adalah saudara Sara. Latar belakang tindakan pencegahan itu adalah bahwa orang Kanaan, penduduk asli dan bangsa kafir itu, tidak berani melakukan perzinahan terbuka dan menghindarkan diri dari perzinahan tersebut sekalipun hal itu terjadi dengan istri orang asing. Sebab perzinahan terbuka dianggap merupakan kesalahan besar yang mengakibatkan kecelakaan. Tetapi untuk membunuh penumpang atau orang asing tersebut orang Kanaan itu tidak bimbang sama sekali supaya dengan demikian ia dapat mewarisi isteri orang itu bersama-sama dengan harta bendanya. Pembunuhan, terutama terhadap orang asing, merupakan kejahatan yang dapat diperdamaikan dengan pembayaran uang ganti rugi (Lempp, 2003). Nampak jelas terlihat bahwa demi menyediakan keselamatannya sendiri, Abraham melacurkan istrinya, sebagai orang yang tidak saleh (Calvin, 1578).

\section{Peringatan dan Tindakan Tuhan}

Raja yang berkuasa di Gerar pada saat itu adalah Abimelekh. Abimelekh ('raja [Tuhan] adalah ayahku') mungkin adalah gelar kerajaan; ada Abimelekh kemudian di pasal 26, dan raja Akhis memiliki nama ini di judul Mazmur 34. Tentang dia mengambil Sarah, Abimelekh merupakan penguasa di Gerar yang luar biasa jujur, bersusila dan adil (Maspaitella, 2014). la tidak segan lagi untuk mengambil Sara karena pengakuan Abraham bahwa Sara adalah sepupunya. Namun Allah tidak tinggal diam menyaksikan kejadian itu dan membiarkan Abimelekh jatuh ke dalam dosa. Pembicaraan Tuhan kepada Abimelekh adalah fiksi sastra yang memungkinkan dialog 
tentang kesalahan Abimelekh. Kejadian 31:24 dan Bilangan 22:9,30 menggunakan teknik yang sama untuk memperkenalkan suatu perikop dengan meminta Tuhan berbicara dalam mimpi; dalam setiap kasus, Tuhan berbicara kepada non-Israel. Kalimat tersebut (Kej 20:3b) diucapkan dalam bahasa hukum sekuler (lih. Yes 38:1). Itu dikenakan untuk kejahatan terhadap properti, seperti yang kita lihat dari klausa tambahan "Dia adalah wanita yang sudah menikah": itu diterima secara luas di dunia kuno bahwa seorang istri adalah milik suaminya. Mengambil seorang wanita yang sudah menikah secara universal dianggap melanggar hak yang disetujui secara ilahi.(Westermann, 1987)

Allah datang memperingatkan Abimelekh melalui mimpi. Allah berfirman kepadanya: "Engkau harus mati oleh karena perempuan yang telah kauambil itu; sebab ia sudah bersuami." (3). Dalam hukum taurat, seseorang yang kedapatan tidur dengan seorang perempuan yang sudah bersuami maka ia dan perempuan itu juga harus dihukum mati sebab itu adalah tindakan yang jahat (bnd. Ul. 22:22). Perzinahan adalah tindakan yang tidak berkenan di hadapan Allah. untuk tujuan menjaga kesetiaan suami-istri. 'Engkau akan mati, karena engkau telah menangkap seorang wanita yang terikat pada seorang suami.' Oleh karena itu, marilah kita belajar, bahwa dalam kata-kata ini sebuah aturan diberikan kepada umat manusia, yang melarang siapa pun untuk menyentuh istri sesamanya. Dan, sungguh, karena tidak ada dalam kehidupan manusia yang lebih suci daripada pernikahan, maka tidak heran, bahwa Tuhan harus menuntut kesetiaan timbal balik untuk dihargai antara suami dan istri dan harus menyatakan bahwa Dia akan menjadi Pembalasnya, sesering itu dilanggar. Dia sekarang alamat dirinya, memang, hanya untuk satu orang; tetapi peringatan harus terdengar di telinga semua orang, bahwa para pezina - meskipun mereka mungkin bersukacita dengan bebas dari hukuman untuk sementara waktu - akan merasa bahwa Tuhan, yang memimpin pernikahan, akan membalas dendam pada mereka (Calvin, 1578).

Mendengar peringatan Allah, Abimelekh terkejut dan tidak menyangka bahwa ternyata ia hampir melakukan tindakan yang jahat di mata Allah. Orang kafir juga mengetahui bahwa perzinahan merupakan perbuatan jahat. Abimelekh sebagai orang kafir hampir melakukan perbuatan tak terpuji itu. Abimelekh menyatakan bahwa ia tidak bersalah karena Abraham sendiri yang mengaku bahwa Sara adalah adiknya jadi dalam hal mengambil Sara, ia melakukannya dengan hati yang tulus dan tidak menyembunyikan apa pun. Abimelekh membela diri karena merasa bahwa dirinya tidak melakukan kesalahan. 
Lalu berfirmanlah Allah kepadanya dalam mimpi: "Aku tahu juga, bahwa engkau telah melakukan hal itu dengan hati yang tulus, maka Aku pun telah mencegah engkau untuk berbuat dosa terhadap Aku; sebab itu Aku tidak membiarkan engkau menjamah dia. Jadi sekarang kembalikanlah isteri orang itu, sebab dia seorang nabi; ia akan berdoa untuk engkau, maka engkau tetap hidup; tetapi jika engkau tidak mengembalikan dia, ketahuilah, engkau pasti mati, engkau dan semua orang yang bersama-sama dengan engkau." (6-7). Allah memerintahkan Abimelekh untuk mengembalikan Sara kepada suaminya yaitu Abraham. Jikalau tidak dikembalikan maka Abimelekh akan mendapat celaka bersama-sama dengan orang yang tinggal dengan dia. Dosa seorang raja tidak hanya berakibat bagi dirinya tetapi juga bagi rakyat yang dipimpinnya. Seluruh rakyat turut juga menanggung hukuman atau siksa yang diakibatkan oleh kejahatan rajanya. Latar belakang dari pengertian hukum itu adalah pendirian mengenai kepribadian-golongan atau kepribadian bangsa.

Peringatan Allah kepada Abimelekh merupakan tanda kasih Allah kepadanya. Allah tidak menginginkan Abimelekh jatuh ke dalam dosa oleh karena itu la mencegahnya untuk berbuat jahat. Allah terlebih dahulu datang memberitahukan tentang hukuman yang akan dia tanggung apabila jatuh ke dalam dosa. NIV menuliskan alasan mengapa Tuhan menghukum Abimelekh ketika dia tidak tahu Sarah sudah menikah, yaitu (1) meskipun niat Abimelekh baik, selama Sarah tinggal di haremnya, dia dalam bahaya berbuat dosa. Seseorang yang memakan jamur payung beracun, mengira itu jamur yang tidak berbahaya, tidak diragukan lagi memiliki niat yang sangat baik, tetapi akan tetap menderita. dosa adalah racun yang merusak kita dan orang-orang di sekitar kita, apapun niat kita. (2) hukuman, mencegah "semua wanita di rumah Abimelekh untuk hamil," hanya berlangsung selama Abimelekh dalam bahaya tidur dengan Sarah. itu dimaksudkan untuk mengubah situasi, bukan untuk menyakiti Abimelekh. (3) hukuman dengan jelas menunjukkan bahwa Abraham bersekutu dengan Tuhan Yang Mahakuasa. kejadian ini mungkin membuat Abimelekh menghormati dan takut akan Tuhan Abraham.

Dalam pembelaan diri Abimelekh, ia berani berhadapan dengan Allah karena hati nuraninya merasa tidak bersalah. la tidak takut untuk membela perkaranya saat berhadapan dengan Allah Israel. Allah pun mengetahui hal itu sehingga ia memperingatkannya. Dalam hal ini, Abimelekh dicegah untuk berbuat dosa dan Abraham dicegah untuk tidak menderita karena kesalahannya terhadap Abimelekh, dan Sara dicegah dari kedua-duanya. Sungguh suatu anugerah Allah apabila 
seseorang dicegah berbuat dosa. setiap teguran dan peringatan Tuhan adalah baik untuk setiap orang yang dikasihi Nya.

\section{Solusi dari Peristiwa}

Abimelekh disuruh untuk memulihkan keadaan seperti semula dengan mengembalikan Sara. Dengan demikian Abimelekh sudah mengetahui bahwa Sara adalah istri Abraham jadi tidak ada alasan lagi baginya untuk merasa tidak bersalah apabila tidak mengembalikan Sara (Kej. 20:14). Abimelekh taat kepada perintah Allah dan merasa bertanggungjawab atas kehidupan orang-orang yang bersama-sama dengan dia. Hal ini menyangkut kehidupan seluruh rakyat sehingga Abimelekh merasa perlu untuk memanggil seluruh hambanya (menterinya) untuk memberitahukan seluruh peristiwa itu kepada mereka. Pengerahan segala hambanya dan pemberitahuan kepada mereka tentang masalah yang terjadi, menandakan bahwa Abimelekh berusaha untuk menyelesaikan masalah itu dengan mendengar pertimbangan dari pada penasehatnya.

Sumber yang menyebabkannya hampir jatuh ke dalam dosa adalah pengakuan Abraham sebagai saudara dari Sara. Oleh karena itu, ia memanggil Abraham untuk meminta penjelasan dari Abraham. la berkata kepada Abraham: "Perbuatan apakah yang kau lakukan ini terhadap kami, dan kesalahan apakah yang kulakukan terhadap engkau, sehingga engkau mendatangkan dosa besar atas diriku dan kerajaanku? Engkau telah berbuat hal-hal yang tidak patut kepadaku. Lagi kata Abimelekh kepada Abraham: "Apakah maksudmu, maka engkau melakukan hal ini?" (9-10). Tiga pertanyaan Abimelekh dalam 9, 10 memperjelas bahwa Abraham hanya bertanya pada dirinya sendiri 'Apa gunanya ini bagiku?', menahan refleksi 'Apa akibatnya bagi mereka?' 'Apa yang pantas mereka dapatkan?' dan 'Apa yang pantas mereka dapatkan? fakta?' (Apa yang kamu lihat?, 10, AV, RV). Akhir dari 9c dapat diterjemahkan menjadi '... hal-hal yang tidak dilakukan':39 dia telah melanggar hukum keramahan yang paling dasar (Kidner, 1967).

Abraham pun hendak membela dirinya. la berkata: "Aku berpikir: Takut akan Allah tidak ada di tempat ini; tentulah aku akan dibunuh karena isteriku. Lagi pula ia benar-benar saudaraku, anak ayahku, hanya bukan anak ibuku, tetapi kemudian ia menjadi isteriku. Ketika Allah menyuruh aku mengembara keluar dari rumah ayahku, berkatalah aku kepada isteriku: Tunjukkanlah kasihmu kepadaku, yakni: katakanlah tentang aku di tiap-tiap tempat dimana kita tiba: la saudaraku." (11-13). Mendengar pengakuan Abraham yang dengan jujur mengakui hubungan yang sebenarnya dengan 
Sara, ia tidak lagi mempersoalkan kesalahan Abraham kepadanya. la kemudian mengambil kambing domba dan lembu sapi, hamba laki-laki dan perempuan, lalu memberikan semuanya itu kepada Abraham, begitu pun Sara dikembalikan juga kepada Abraham dan ia memberi kebebasan untuk tinggal di daerahnya dimanapun yang ia suka. Abimelekh juga memberikan seribu syikal perak sebagai bukti kesucian Sara (14-16). Walaupun tampak bahwa Abimelekh tidak bersalah dan tidak menyadari kesalahan apapun, namun melalui pertemuannya dengan Abraham ia bertemu dengan Allah yang disembah Abraham. Melalui itu Abimelekh menyadari kesalahannya yang turut campur tangan dalam kehidupan pernikahan Abraham dan ia pun mulai takut kepada kuasa Allah yang disembah Abraham. Pemberian uang sebanyak seribu syikal itu menunjukkan bahwa Abimelekh hendak memulihkan nama baik Sara dan mengembalikan kehormatan Sara. Pemberian kambing domba dan lembu, termasuk hamba laki-laki dan perempuan, bukanlah harga beli atau upah sundal, melainkan sebagai pendamaian dan pengganti kerugian buat Abraham yang telah dirampas istrinya dengan tidak sah itu. Secara subyektif Abimelekh tidak bermaksud berbuat zinah, tetapi ia melakukan penculikan manusia. Atas kejahatan tersebut haruslah juga dijatuhkan, menurut hukum Israel, hukuman mati. Penculikan manusia hanya dapat dipulihkan dengan pembayaran manusia berlipat ganda. Abimelekh mencoba memperbaiki, memulihkan dan membayar pendamaian seluruhnya, sepanjang pengetahuannya dan keinsafannya terhadap hukum yang berlaku.

Kerugian materil dan moril telah diganti oleh Abimelekh kepada Abraham sepenuhnya. Tetapi kesalahan di hadapan Allah tidak dapat dihapuskan dan diampuni sebab pengampunan Allah tidak dapat dibeli atau dengan usaha sendiri. Pengampunan itu bergantung sama sekali kepada pengantara (penengahan) orang pilihan Allah. Hormat dari manusia mungkin dapat dipulihkan, tetapi hormat dari pihak Allah sendiri tidak dapat dipulihkan oleh usaha manusia kafir, melainkan hanya didoakan oleh seorang yang menerima perjanjian berkat-Nya. Abraham adalah orang pilihan Allah sehingga kesalahan Abimelekh hanya dapat dihapuskan atau diampuni dengan didoakan oleh Abraham. Melalui doa Abraham, Allah menyembuhkan Abimelekh dan istrinya dan budak-budaknya perempuan, sehingga mereka melahirkan anak (17). Abraham melepaskan Abimelekh dari hukuman Allah. Dengan berdoa bagi musuhnya dan mengampuni mereka, maka Abraham sendiri menerima keampunan Allah kembali (bnd Ayb 42:10). Hukuman Allah yaitu kemandulan terhadap perempuan di istana Abimelekh (18) adalah seimbang dengan kesalahannya 
yang objektif, yaitu perusakan keluarga dan keturunan Abraham. Dalam bukunya, Derek Kidner juga menyatakan Pemberian Abimelekh yang mewah menunjukkan rasa hormatnya terhadap kekuasaan yang dimiliki oleh Abraham, yang syafaatnya masih ia butuhkan (lihat 17, 18), dan harus menentukan arti dari yang sulit. Oleh karena itu, penghinaan yang diungkapkan dalam AV adalah salah; itu harus dibaca seperti dalam $\mathrm{RV}$ : itu adalah penutup mata yaitu 'itu akan menghalangi semua kritik'. Kata kerja terakhir, biasanya berarti menegur (AV), dapat berarti 'terbukti', seperti dalam Ayub 13:15, dan bahkan 'disetujui' (Kej 24:14). Dalam menawarkan kompensasi Abimelekh mengakui kesalahannya (meskipun istilah saudaramu kembali menekankan ketidakbersalahannya), dan dalam menerimanya Abraham mengakui masalah itu telah diselesaikan (Kidner, 1967). Dapat dikatakan, sebagaimana Abimelekh memulihkan kehormatan Abraham di hadapan manusia, demikianlah Abraham mengembalikan kehormatan (pembenaran) Abimelekh di hadapan Allah.

\section{Hospitalitas Abimelekh dan Relevansinya Terhadap Peringatan yang Disertai Kekerasan}

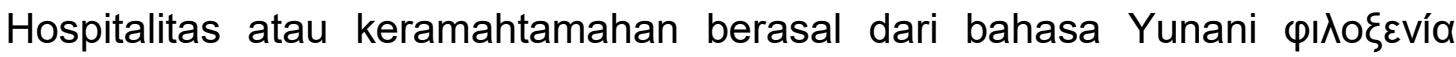
(philoxenia) yang terdiri dari dua kata yaitu, philos (kasih) dan xenos (orang asing, yang lain). Kata tersebut secara literal berarti mencintai yang lain, mencintai orang asing.(Susanta, 2015) Hospitalitas sejati berarti, tidak hanya menyediakan rumah bagi orang asing yang kita jumpai, tetapi juga menjadi nyaman dan kerasan (at home) dengan diri kita sendiri. Hospitalitas lebih daripada suatu tindakan. Bahkan lebih daripada suatu keadaan pikiran yang kita bangkitkan sekarang dan demi kebaikan kita. Hospitalitas merupakan suatu cara khusus memandang dunia. Ini suatu pilihan. Kita menolak kecurigaan terhadap orang asing sebagai reaksi pertama. Kita memilih untuk melayani di samping orang lain daripada pelayanan terhadap mereka. Kita memilih membiarkan beberapa orang luar pengawasan kita ketika kita menjumpai orang asing (Hersberger, 2009). Seseorang yang hendak menyatakan tindakan hospitalitas mendasarkan pada kasih tanpa terkecuali. Tidak dapat dipungkiri bahwa tindakan hospitalitas dirasakan tidak menyenangkan dan tidak pasti (Hersberger, 2009). Akan ada yang merespon kedatangan orang asing dengan tidak baik karena merasa tertekan dan tidak nyaman dengan kehadiran mereka sehingga tindakan hospitalitas terasa sulit didapatkan orang asing.

Kisah Abimelekh yang menyatakan hospitalitas kepada Abraham menjadi potret bahwa hospitalitas bukanlah tanpa resiko. Seperti tuan rumah yang membuka pintunya bagi orang asing, ada kemungkinan orang asing tersebut justru akan 
menyalahgunakan kebaikan yang ia terima dari sang tuan rumah. Hal itu berarti, hospitalitas adalah hal yang berisiko (Susanta, 2015). Tindakan Abraham yang menyalahgunakan kebaikan dari sang tuan rumah memperlihatkan bahwa ia tidak menghargai keramatamahan dari sang raja. Abraham telah melakukan kebohongan kepada Abimelekh atas status hubungannya dengan Sarai. Memang Sarai juga saudara tiri Abraham (Kejadian 20:12), namun menggunakan separuh kebenaran untuk menyembunyikan separuhnya lagi adalah dianggap suatu kebohongan (Damarwanti, 2019) dan secara diam-diam Abraham mengakui hal ini ketika ia mengajukan pembelaan atas perbuatannya. Memang tujuan Abraham tercapai, yaitu bahwa Abimelekh memperlakukan dia dengan baik. Abimelekh yang dikelabui dengan kebohonga Abraham justru mendapat peringatan keras dari Allah. Tetapi ingatan menampakkan nilai kebajikan ketika ditujukan untuk mengarahkan seseorang berbalik dari perilaku menyimpang. Inilah yang menjadi alasan dari penghukuman Allah terhadap Abimelekh, walaupun Abimelekh memiliki niat yang baik namun ketika Sara tetap berada dalam kekuasaannya, maka ia berada dalam bahaya untuk berbuat dosa. Hukuman Allah yaitu kemandulan terhadap perempuan di istana Abimelekh hanya berlangsung selama Abimelekh berada dalam bahaya untuk tidur dengan Sara. Hal itu bertujuan untuk mengubah situasi yang ada dan bukan untuk mencelakakan Abimelekh. Hukuman itu jelas menunjukkan bahwa Abraham mempunyai ikatan dengan Allah sehingga melalui peristiwa peringatan yang terjadi atas Abimelekh, menyebabkan Abimelekh menghormati dan takut pada Allah Abraham.

Belajar dari kisah Abimelekh bahwa dalam kehidupan sehari-hari, peringatan disertai kekerasan hendak mendatangkan maksud yang baik dan bukan mencelakakan. Sesuatu yang menurut kita baik, belum tentu baik menurut kehendak Tuhan, sehingga ketika Tuhan menegur kita, maka sama seperti Abimelekh yang segera menyadari kesalahannya dan menyelesaikan masalah yang terjadi, demikianlah juga yang perlu kita lakukan.

\section{KESIMPULAN}

Tindakan hospitalitas yang dilakukan oleh Abimelekh terhadap Abraham bukanlah tanpa resiko. Abimelekh justru mendapatkan peringatan yang keras dari Allah. Tetapi sesungguhnya peringatan Allah kepada Abimelekh merupakan tanda kasih Allah kepadanya. Allah tidak menginginkan Abimelekh jatuh ke dalam dosa oleh karena itu la mencegahnya untuk berbuat jahat. Allah terlebih dahulu datang memberitahukan tentang hukuman yang akan dia tanggung apabila jatuh ke dalam 
dosa. Dalam hal ini, Abimelekh dicegah untuk berbuat dosa dan Abraham dicegah untuk tidak menderita karena kesalahannya terhadap Abimelekh, dan Sara dicegah dari kedua-duanya. Sungguh suatu anugerah Allah apabila seseorang dicegah berbuat dosa. setiap teguran dan peringatan Tuhan adalah baik untuk setiap orang yang dikasihi Nya.

Alasan mengapa Tuhan menghukum Abimelekh ketika dia tidak tahu Sarah sudah menikah, yaitu (1) meskipun niat Abimelekh baik, selama Sarah tinggal di haremnya, dia dalam bahaya berbuat dosa. Dosa adalah racun yang merusak kita dan orang-orang di sekitar kita, apapun niat kita. (2) hukuman, mencegah "semua wanita di rumah Abimelekh untuk hamil," hanya berlangsung selama Abimelekh dalam bahaya tidur dengan Sarah. itu dimaksudkan untuk mengubah situasi, bukan untuk menyakiti Abimelekh. (3) hukuman dengan jelas menunjukkan bahwa Abraham bersekutu dengan Tuhan Yang Mahakuasa. kejadian ini mungkin membuat Abimelekh menghormati dan takut akan Tuhan Abraham. Dengan demikian, dapat dikatakan bahwa ingatan menampakkan nilai kebajikan ketika ditujukan untuk mengarahkan seseorang berbalik dari perilaku menyimpang.

\section{DAFTAR PUSTAKA}

Alexander, P., \& Tarmedi, D. (2013). Analisis Naratif: Sebuah Metode Kristiani Hermeneutika Kitab Suci. Melintas, 29(3), 331-360.

Calvin, J. (1578). Commentary on Genesis - Volume 1 (Vol. 1). MI: Christian Classics Ethereal Library.

Damarwanti, S. (2019). MEMPERTANYAKAN GELAR ABRAHAM SEBAGAI BAPA ORANG. Sanctum Domine, 9(1), 10-20.

Hersberger, M. (2009). Hospitalitas - Orang Asing Teman Atau Ancaman? BPK Gunung Mulia.

Kidner, D. (1967). Genesis An Introduction And Commentary. Tyndal Press.

Lempp, W. (2003). Tafsiran Alkitab Kitab Kejadian Pasal 12:4-25:18. BPK Gunung Mulia.

Maspaitella, E. (Ed.). (2014). Tafsiran Alkitab Wycliffe Volume 1 Kejadian - Ester. Gandum Mas.

Susanta, Y. K. (2015). Hospitalitas Sebagai Upaya Mencegah Kekerasan Dan Memelihara Kerukunan Dalam Relasi Islam-Kristen Di Indonesia. SOCIETAS $D E I, 2(1)$.

Westermann, C. (1987). Genesis. T\&T Clark. 
